\title{
The Difference Test of Debt Expansion of Urban Financing Platform
}

\author{
Yin Huayang ${ }^{1}$, Xia Tingting ${ }^{1, ~ a ~}$, Cui Bing ${ }^{1}$, Zhou $\mathrm{Di}^{1}$ \\ ${ }^{1}$ School of economics and management, Hubei University of Technology, Wuhan 430000, China \\ ${ }^{a}$ Xia Tingting:xiatingtinglmz@163.com
}

Keywords: location characteristics; local financing platform debt; financial decentralization; fiscal and financial coordination

Abstract: Combining the location characteristics of provincial capitals and municipalities, from the perspective of fiscal financial decentralization system, the different expansion of local debt financing platform is studied to find out that the degree of financial fiscal decentralization is the main institutional incentives of local financing platform debt expansion difference, and Shanghai and Hangzhou have obvious location advantages. The advantages of these factors may include the development of the financial industry, the development of the Internet and other factors.

\section{Introduction}

Government debt, especially local government debt, is a universal question in the world. Since the 1980s, foreign scholars have begun to distinguish between central government debt and local government debt in government debt research, and gradually strengthened research into local government debt. With economic development, the focus of the local government debt problem has also gradually shifted from borrowing debt to debt management issues that address the inflation of local government debt. The debt based debt platform is valued at the level of the state department, with a range of policies and policies to govern.

Although the new budget law will add local debt financing platform out of local government debt, but the debt of local financing platform to provide financial support for indirect light fiscal pressure. From the perspective of institutional incentives, local financing platform debt and local government debt problems are caused by soft constraints, there are literature also demonstrates this fact, such as a column, Wang Jie (2013) demonstrated financial soft constraints is an important financial result in the formation and development of local financing platform. In summary, the local financing platform debt expansion incentives to large extent can explain the expansion of local government debt, and the analysis of governance will expand to local government debt to provide ideas for the expansion of local government debt system. The theoretical analysis of incentives is cited to the debt expansion of local financing platform. 


\section{Research Design}

\subsection{Research data and samples}

Choose the size of the city investment bond as a reflection of the size of the local financing platform debt statistics. For the selection of more characteristic areas, the provincial capital city investment debt issue can be used as a benchmark for the province, reflecting the overall situation of a province, can be used as a better sample study interval, so choose to provincial cities and municipalities as a representative city, wind information data show that in 2004 only Beijing, Hangzhou, Zhengzhou, three representative capital cities issued city investment debt, in order to better explain the cross-regional differences, select the sample for which city issued the city investment debt every year during 2005 to 2015.The representative capital cities are: Shanghai, Beijing, Nanjing, Guangzhou, Hangzhou, Chongqing, Tianjin, Nanchang, Chengdu, Wuhan.

\subsection{Research hypothesis}

According to the development center of the State Council report on the various regions, in the past four plate is divided into eight integrated economic area, which is representative of the selected City Economic Zone: the eastern coastal economic zone, the southern coastal economic zone, north of the coastal economic zone, the middle reaches of the Yangtze River Economic District, southwest economic area. The focus here is to look for cities that are worth learning from, and further explore possible locational characteristics, which are illustrated below.

\subsubsection{The easterm coastal economic zone}

The eastern coastal economic zone include Shanghai, Nanjing, Hangzhou in sample.

1) Shanghai as a national financial center is different from other representative cities of the important features. Liu Mingkang (2008) deemed that outstanding advantages always existed in Shanghai. [2] The development of the financial industry is closely linked with the financing of the local financing platform. It also provides more local financing channels to improve the efficiency of capital utilization. The government can directly or indirectly support local investment and construction through other channels other than borrowing and further reduce the local financing platform financing needs.

2) Nanjing area in addition to the economic zone with the same advantages, compared with Shanghai and Hangzhou, there are more obvious historical features. Zhang Lianhong (2000) considered that the Nanjing Massacre has a serious social and psychological impact on the people of Nanjing, which is still continued so far; After the victory of the Anti-Japanese War, the National Government has been in a serious state of fiscal deficit, not only that, the National Government's series of erroneous policies makes the deficit surge, debt, heavy taxes. Due to the complete destruction of the Nanjing economy and the Nanjing people's mind damage, the difficulty of reconstruction of Nanjing can be imagined. These historical factors have a significant impact on the economic and social development of Nanjing and local fiscal revenue, and further increase the possibility of local governments developing their economy through borrowing.

3) Hangzhou, the Internet and other emerging industries developed, can promote economic development more efficient. Yang Yiqing (2015) deemed that Zhejiang is China's most influential based on the same cultural background of entrepreneurial groups, Zhejiang Province, the overall strength of private economy ranks first in the country, Zhejiang private enterprises will inevitably contribute to the development of a large number of tax revenue to reduce the local government's financial pressure, thereby reducing the local government debt motivation. Hangzhou, a strong 
economic foundation, its inherent charm also contributed to the G20 summit settled in Hangzhou, but the economic development and financial level, Hangzhou still have a certain gap to shanghai.

Hypothesis 1: The positive impact of location characteristics on the size of the local financing platform is Nanjing area> Hangzhou area> Shanghai area.

\subsubsection{The southern coastal economic zone}

The southern coastal economic zone only include Guangzhou in sample. Li Shilan (2015) deemed that the Guangzhou region has a long history of business, a unique location and transportation hub advantages, a high degree of openness, is the estuary harbor, a first-tier cities, economic and other aspects of development advantages.

\subsubsection{The north of the coastal economic zone}

The north coastal economic zone only include Beijing, Tianjin.

1) Beijing as the only political center of the country's special status is unique, but also different from other representative cities of the important features. Wang Shulin (2009) considered that Beijing's economic development of the greatest advantages and resources, as the national political center of the capital or capital resources, this feature will attract talent to attract foreign investment, a large number of excellent resources concentrated in the Beijing area, to promote the Beijing economy .The rapid development and local fiscal revenue to improve, to a certain extent, reduce the local government to develop economic incentives for borrowing.

2) Tianjin area as a municipality, enjoy the resources and the general capital of the city will be different, while the Gulf River port, Tianjin, as the largest port in the north, the economic development of the location advantage is huge. But compared with Beijing in terms of local financial or regional economic point of view there will still be a big gap.

Hypothesis 2: The positive impact of location characteristics on the size of the local financing platform is Tianjin> Beijing.

\subsubsection{The middle reaches of the Yangtze River Economic District}

The middle reaches of the Yangtze River Economic District include Wuhan, Nanchang in sample.

1)Wuhan area Wuhan is called "nine provinces thoroughfare", there are rich soil and water elements of the environment, the top talent conditions, financial pressure than Nanchang small, borrowing pressure will be smaller.

2) Nanchang region has a relatively rich historical and cultural resources and natural resources, but the direct contribution to the local finance is not significant, the debt pressure compared to Wuhan will be bigger.

Hypothesis 3: The positive impact of location characteristics on the size of the local financing platform is Nanchang $>$ Wuhan.

\subsubsection{The southwest economic area}

The southwest economic area include Chengdu, Chongqing in sample.

1) Chongqing is rich in natural resources, For the Southwest Economic Zone of heavy chemical industry center, at the same time as a municipality, compared with Chengdu, a greater economic and financial advantages.

2) Chengdu has a certain degree of technological advantages, but from the city scale, economic base, especially the manufacturing base and other areas as a municipality compared to Chongqing, a 
certain gap, Chengdu may have greater financial pressure, but also greater borrowing motivation.

Hypothesis 4: The positive impact of location characteristics on the size of the local financing platform is Chengdu> Chongqing.

\subsection{Model design}

Using the panel data to construct the regression model with intercept term, see equation (1) Specific variables are shown in Table 1.

$$
D R_{i, \boldsymbol{t}}=\beta 0+\beta_{1} \text { fisd }_{\boldsymbol{i}, \boldsymbol{t}}+\beta_{2} \text { finc }_{\boldsymbol{i}, \boldsymbol{t}}+\beta_{3} \text { fisd }_{\boldsymbol{i}, \boldsymbol{t}} * \text { finc }_{i, t}+\xi_{\boldsymbol{i}, \boldsymbol{t}} ;
$$

Table 1 Definitions of variables

\begin{tabular}{|c|c|c|}
\hline $\begin{array}{l}\text { Variable } \\
\text { code }\end{array}$ & Variable name & Variable definition \\
\hline GDP & $\begin{array}{ll}\text { Gross } & \text { domestic } \\
\text { product } & \end{array}$ & Gross domestic product of the country \\
\hline gdp & Regional GDP & Regional GDP \\
\hline DR & $\begin{array}{l}\text { Local government } \\
\text { debt ratio }\end{array}$ & $\begin{array}{l}\text { The city investment debt scale represents the local } \\
\text { financing platform debt scaleaccounts for represents } \\
\text { the total size of all local financing platform debt }\end{array}$ \\
\hline fisd & $\begin{array}{l}\text { Relative degree of } \\
\text { fiscal } \\
\text { decentralization }\end{array}$ & $\begin{array}{l}\text { Local finance divides the relative capacity of the } \\
\text { national revenue }\end{array}$ \\
\hline finc & $\begin{array}{l}\text { Relative degree of } \\
\text { financial } \\
\text { decentralization }\end{array}$ & $\begin{array}{l}\text { Local finance divides the relative capacity of } \\
\text { national financial resources }\end{array}$ \\
\hline fisd*finc & $\begin{array}{l}\text { Degree of } \\
\text { interaction between }\end{array}$ & $\begin{array}{l}\text { Financial and financial parallel interaction, mutual } \\
\text { supervision and coordination }\end{array}$ \\
\hline & $\begin{array}{ll}\text { finance } & \text { and } \\
\text { Finance } & \end{array}$ & \\
\hline
\end{tabular}

\section{Result Analysis}

\subsection{Regression analysis results}

It shows significance in table 2.

Table 2 Variable coefficient

\begin{tabular}{crrrr}
\hline Variable & Coefficient & Std. Error & t-Statistic & \multicolumn{1}{c}{ Prob. } \\
$\beta 0$ & -0.1170 & 0.0158 & -7.4248 & 0.0000 \\
Fisd & 2.0519 & 0.1320 & 15.5495 & 0.0000 \\
Finc & 0.7012 & 0.0718 & 9.7643 & 0.0000 \\
Fisd*Finc & -5.5177 & 0.4406 & -12.5228 & 0.0000 \\
\hline
\end{tabular}

\subsection{Analysis of Location Differences}

\subsection{1 fiscal/finance effects}

From the above statistics, we can see that the higher the degree of fiscal / financial decentralization, the greater the scale of local financing platform debt, fiscal financial synergy is 
stronger, the smaller the local financing platform debt. Different regional fiscal / financial decentralization is the important reason for the different degree of debt expansion in local financing platforms. This empirical conclusion provides a way for local financial and financial coordination to local financing platform.

\subsubsection{Location factor}

Table3 Individual fixed effect values

\begin{tabular}{lll}
\hline \hline Cross & Fixed Effects & \multicolumn{1}{c}{ Value } \\
-SH--C & -0.2188 & -0.3358 \\
-NJ--C & 0.1239 & 0.0069 \\
_BJ--C & -0.0893 & -0.2063 \\
_GZ--C & 0.0129 & -0.1041 \\
_HZ--C & 0.0105 & -0.1065 \\
_CQ--C & 0.0110 & -0.1060 \\
-TJ--C & 0.0224 & -0.0946 \\
_NC--C & 0.0656 & -0.0514 \\
_CD--C & 0.0338 & -0.0832 \\
_WH--C & 0.0279 & -0.0891 \\
\hline
\end{tabular}

It shows significance in table 3.

1) From the perspective of individual fixed effect, the eastern coastal economic zone, Shanghai $<$ Hangzhou $<$ Nanjing, verified the hypothesis 1 ; the northern coastal economic zone, Beijing $<$ Tianjin, verify the hypothesis 2; Yangtze River Economic Zone, Wuhan $<$ Nanchang, verify the hypothesis 3; Southwest Economic Zone, Chongqing <Chengdu, verify the hypothesis 4.

2) Only the fixed effect of Beijing and Shanghai is negative, which indicates that the regional characteristics of the two cities have a significant negative impact on the scale of the local financing platform, and the regional characteristics of the Shanghai area can promote the local government to reduce the borrowing. Xie et al. (2009), taking Beijing and Shanghai as examples, shows that regional financial development has a positive effect on regional economic growth, and pointed out that Shanghai's financial development is more positive than that of Beijing's financial development The Shanghai's financial industry is more developed than Beijing, but also to promote the Shanghai area on the scale of local government debt impact of more than Beijing, indicating that the level of financial development in Shanghai may exceed the Beijing area of the capital advantage can bring the negative To influence. It can be seen that the development of the financial industry may play a very important role in alleviating the degree of debt expansion of local financing platform, which also provides a useful factor for other local areas to reduce the size of local debt.

3) In addition to Shanghai and Beijing, the individual fixed effect of Hangzhou area is the smallest, the development of new industries such as the Internet may plays a very important role, these location characteristics can also be used in some areas.

4) Only the final intercept of the Nanjing area is positive, the impact of the scale of the debt is positive, indicating that the location characteristics of Nanjing may have a very large impact, the Nanjing area can consider the use of Shanghai or Hangzhou area, may be better to reduce the local financing platform for debt expansion.

5) In addition to the Nanjing area, the local financing platform for the largest impact of Nanchang, mainly due to the relatively backward level of economic development. 


\section{Conclusion}

According to the differentiated performance of the expansion of the local financing platform of the provincial capital cities, the analysis shows that Shanghai and Hangzhou are worthy of reference. In addition to the level of economic development, the degree of development of the financial industry and the development of new industries such as the Internet may also be important factors.

\section{Acknowledgements}

Project supported by the National Social Science Fund of China: financial and Financial Cooperative Governance of local government debt under the dual soft budget constraint (item number: 15BJY143)

\section{References}

[1] Ma zhu, Wang Jie. Exploring the causes of the local financing platform -- a new vision of vertical financial competition -- [J]. economist, 2013,05:57-64.

[2] Tiebout C M. A pure theory of local expenditures[J]. The journal of political economy,1956: 416-424.

[3] Musgrave R A. Theory of public finance; a study in public economy [J]. 1959.

[4] Oates W E. Fiscal federalism[J]. Books, 1972.

[5] Kornai J. The soft budget constraint[J]. Kyklos, 1986, 39(1): 3-30.

[6] Wildasin D E. Externalities and bailouts: hard and soft budget constraints in intergovernmental fiscal relations[M]. World Bank Publications, 1997.

[7] Rodrik D, Velasco A. Short-term capital flows[R]. National bureau of economic research, 1999.

[8] Gong Qiang, Wang Jun, Jia Kun. Research on local government debt from the perspective of Fiscal Decentralization: a review [J]. economic research, 2011 (7): 144-156.

[9] Xu chengang. China debt problems [D].2010.

[10] Wang, xuguo, Zhang Guangting, Shen Hongbo. Fiscal decentralization, promotion incentives and soft budget constraints. An analytical framework for excessive indebtedness of local governments [J]. finance research, 2012 (3): 10-15.

[11] Xu Poling, Zheng Yanxia. The mechanism of local debt in China and India under fiscal decentralization [J]. Asia Pacific economy, 2012, 3: 30-36.

[12] Ge Hejun, Gou ting. Chinese local government financing platform credit risk research on [J]. dynamic economics, 2011 (1): 77-80.

[13] Shi Chaoyang. Economic growth under the perspective of China's local government debt problem [D]. Huazhong University of Science and Technology, 2012. (Social Science Edition) Journal of East China Institute of Technology

[14] Liu Mingkang. Shanghai to build international financial center of the advantages and gaps [J]. China Economic Weekly, 2008,25: 15.

[15] Zhang Lianhong. Nanjing Massacre on the Nanjing social psychology of the impact [J]. Jiangsu Social Sciences, 2000,06: 109-113.

[16] Sun Zhai Wei. After the victory of the war in Nanjing government financial situation analysis [J]. Historical archives, 1992,01: 126-132.

[17] Yang Yiqing. Low "population quality" and high economic growth - based on the interpretation of Zhejiang compatriots [J]. Population Research, 2015, (03): 107-112.

[18] Li Shilan. Strategic Thinking on the Reconstruction of Guangzhou's Open Economy by Maritime Silk Road [J]. Development, 2015,04: 5-9.

[19] Wang Shulin. Capital advantage: the core strengths of Beijing's development of the economy [J]. New vision, 2009, (05): 57-60.

[20] Zhang Meng. Tianjin economic development and port advantages [J]. Nankai Economic Research, 1996,03: 46-49.

[21] Guo Zi. Yangtze River in the middle of Wuhan Economic Zone development strategy research essence [J]. Science and Technology Progress and Countermeasures, 2002,08: 42-44.

[22] Zhu Lifeng. On the development of Nanchang city [J]. Jiangxi University of Finance and Economics, 2007,03: 5-9. 